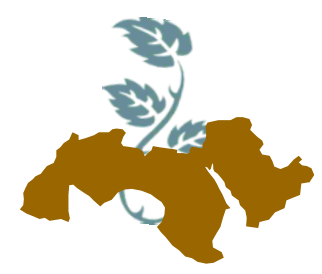

1573

Arab Univ.

J. Agric. Sci.,

Ain Shams Univ., Cairo

Special Issue, 26(2B), 1573-1584, 2018

\title{
HEPATOPROTECTIVE EFFECTS OF MORINGA OLEIFERA EXTRACTS ON ACETAMINOPHEN-INDUCED OXIDATIVE DAMAGE IN RATS
}

\author{
Dina H. El-Gannam ${ }^{1}$, Ramadan ${ }^{1}$ K.M.A., Nermin Z. Teleb ${ }^{2}$ \\ and El-Aasar ${ }^{1}$ A.M. \\ 1- Biochemistry Dept., Fac. of Agric., Ain Shams Univ., P.O. Box 68, Hadayek Shobra 11241, \\ Cairo, Egypt \\ 2- National Organization for Drug Control and Research, Giza, Egypt
}

Keywords: Moringa Oleifera Lam, Ethanolic extracts, Hepatoprotective, Antioxidants

\section{ABSTRACT}

This study aimed to evaluate the in-vitro antioxidant activities of Moringa Oleifera Lam (MO) extracts, and their protective effects in acetaminophen (APAP)- induced liver injury in rats caused by oxidative damage. The antioxidants activities of ethanolic, aqueous and hexane extracts of different $\mathrm{MO}$ edible parts were investigated by $\mathrm{DPPH}$ radical scavenging capacity and malondialdehyde (MDA) assays. The ethanolic extracts of different parts of MO were found to have higher antioxidant capacity compared to the aqueous and hexane extracts. The flowers ethanolic extract has the highest total antioxidants capacity among the other different parts of MO follo wed by leaves, pods, roots and finally seeds. HPLC-MS scanning of ethanolic leave extracts showed the presence of flavonoid derivates Apigenin, quercetin and kaempferol in addition to chlorogenic acid. In the hepatoprotective study, either leaves or pods extracts $(300 \mathrm{mg} / \mathrm{Kg}$ bw or $600 \mathrm{mg} / \mathrm{Kg}$ bw stomach tube orally) were administrated to rats one hour prior to administration of a single dose of APAP ( $4 \mathrm{~g} / \mathrm{Kg}$ bw by stomach tube orally). The hepatoprotective activity of $\mathrm{MO}$ leaves and pods extracts were followed for 21 days by observed in the levels of liver markers such as alanine aminotransferase (ALT) and the levels of oxidative damage markers including superoxide dismutase (SOD) and malondialdehyde (MDA) and catalase (CAT), wich analysed and compared between groups pretreated with MO extracts +APAP to those treated with
APAP alone. The outcome of this parameters indicate reduction in the severity of liver damage in group treated with MO extracts + APAP and compared to those treated with APAP alone. Also, histopathological examination of liver tissues of rats treated with $\mathrm{MO}$ extracts showed an improvement at the end of experiment. The results of this study indicate the hepatoprotective properties of MO leaves and pods ethanolic extracts against liver injury and thereby signify its traditional use.

\section{INTRODUCTION}

Liver diseases are a major global concern, and this type of disease / disorder still has extremely poor prognosis and high mortality because of the lack of effective preventive /treatment options. The population of Egypt has a heavy burden of liver disease, mostly due to chronic infection with hepatitis $\mathrm{C}$ virus (HCV) (Christina, et al 2000).

Oxidative stress due to high levels of reactive oxygen species (ROS) and reactive nitrogen species (RNS) is a common mechanism contributing to initiate initiation and progress of hepatic injury in variety of liver disorders. Various indogenous factors (such as alcohols, drugs, environmental toxins ,virus and UV light) may cause oxidative stress in liver (Sha Li, et al 2015). Moreover systemic oxidative stress arising during liver disease can also cause damage to extra-hepatic organs, such as brain impairment and kidney failure (Palma, et al 2014). Application of natural antioxidants signifies a rational curative strategy to prevent and cure liver diseases involving oxidative stress. Several studies showed that hepatoprotective effects of medicinal plants associated with natural antioxi- 
dants (Sharida Fakuraz, et al 2012). Moringa Oleifera Lam (MO) is a highly valued plant, having remarkable range of Pharmacological properties in addition to significant nutrition value. The various parts of MO plant such as roots, leaves, flowers, gum bark, fruit, seeds and seed oil have been used for various aliments in the indigenous medicine of south Asia, especially in India, including the treatment of inflammation and infectious diseases along with cardiovascular and hepatorenal disorder (Anwar, et al 2007) The methanolic extract of $\mathrm{MO}$ edible parts showed strong in vitro antioxidant properties, which is due to the presence of various bioactive compounds such as chlorogenic acid, rutin, quercetin glucoside (Atawodi et al 2010) Moreover, the extract of Moringa oleifera leaves and other parts of plant have been shown to have potent antioxidant action in vivo (Ashok and Pari, 2003; Streelatha and Padma, 2011; Sharida, et al 2012). Acetaminophen (paraacetamol) is most widely used in the world as an analgesic and antipyretic drug for humans, that is save at therapeutic dosages. However, it's also known to cause hepatic necrosis and renal failure in humans (Jaeschke and Bajt, 2006) and animals (Sharida Fakuraz, et al 2008). Oxidative stress is reported to play a role in the pathogenesis in acetaminophen - induced liver and renal damages. Therefore, models of acetaminophen - induced in liver damage in mice / rate were used to study antioxidant and hepatoprotective effects of natural antioxidant and medicinal plants.

The objective of this study were to (1) evaluate and compare in vitro total antioxidant capacity of different parts (leaves, Flowers, roots, pods and seeds) of Moringa oleifera Lam (MO) extracts, (2) evaluate the adverse effects induced by oral of acetaminophen (APAP) in an overdose on hepatotoxicity of experimental rats, (3) evaluating the antihepatotoxic potential of ethanolic extracts from $\mathrm{MO}$ leaves and pods on APAP-induced liver toxicity in experimental rats.

\section{MATERIALS AND METHODS}

\section{Plant collection}

Moringa Oelifera (MO) plant were collected from farm of the Egyptian scientific society farm of Moringa at National Research Center; Giza, Egypt., August 2016. The collected parts (leaves, seeds, roots and pods) were washed thoroughly with distilled water and air- dried.

\section{Preparation of MO extracts}

Different parts of MO (leaves, flowers, seeds, roots and pods) were stepwise extracted using hexane (60-80\%), ethanol (95-96\%) and distilled water. One $\mathrm{Kg}$ of each dried powder part and $103.45 \mathrm{~g}$ of fresh flowers were susceptible for extraction by soaking overnight at room temperature three times. Extracts were then evaporated to dryness at $40-45^{\circ} \mathrm{C}$ at reduced pressure by using rotary evaporator. Extracts of hexane, ethanol and distilled water were taken for analysis of antioxidant activities.

\section{Determination of (DPPH) radical scavenging activity}

DPPH radical scavenging activity was measured by determins the decrease in absorbance of the ethanolic DPPH solution at $517 \mathrm{~nm}$ in the presence of MO extracts as described by BrandWiliams, et al (1995). In brief $0.5 \mathrm{ml}$ extract sample $(12 \mathrm{mg} / \mathrm{ml})$ was added to $0.3 \mathrm{ml}$ ethanolic solution of DPPH $(0.05 \mathrm{mM})$ and the total volume made up to $3 \mathrm{ml}$ with ethanol. The reaction mixture were vortexed and allowed to stand for $100 \mathrm{~min}$ at room temperature in the dark before the absorbance was measured using solvent ethanol as blank. The percentage of free radical scavenging activity was calculated from the following equation:-

$$
\% \text { inhibition }=\frac{A \text { cont }- \text { A sample }}{A \text { Standard }} \times 100
$$

Wheres: $A_{\text {cont }}=$ absorbance of standared DPPH solution used in experiment with all reagent except sample.

Determination of lipid peroxidation (LPO) measurement of MDA- TBARS.

Malondialdehyde (MDA) was measured by thiobarbituric acid reactive substances (TBARS). TBARS of Oil-MO extracts mixtures was determined according to Tamura and Shibamoto (1991). The reaction mixture consists of $0.5 \mathrm{ml}$ of oil-extract mixture $(0.1 \mathrm{mg}$ of sunflower oil- $12 \mathrm{mg}$ MO extract), $1 \mathrm{ml}$ thiobarbituric acid (TBA) $0.3 \%$ and $1 \mathrm{ml}$ trichloroacetic acid (TCA) $10 \%$. mixture was heated for $30 \mathrm{~min}$ at $95^{\circ} \mathrm{C}$ in water bath. After cooling, $1 \mathrm{ml}$ chloroform was added, and the reaction mixtures were centrifuged at $1000 \times \mathrm{g}$ to give clear supernatants. Absorbance of the supernatants was measured at $532 \mathrm{~nm}$. The extinction coefficient of TBA-malondialdehyde product of 


\section{Hepatoprotective effects of Moringa oleifera extracts on acetaminophen-induced 1575}

oxidative damage in rats

$1.56 \times 105 \mathrm{M}-1 \mathrm{~cm}-1$ was used to convert absorbance values into concentrations of $\mathrm{mmol} \mathrm{MDA} / \mathrm{g}$ oil.

Identification of compounds in MO extracts by HPLC-MS

Qualitative analyses was carried out by high performance liquid chromatography using an $\mathrm{Ag}$ ilent LC-MS 1200. Phenolics and flavonoids were characterized in ethanolic extracts of leaves of $\mathrm{MO}$ by chromatographic comparisons with standards (retention time, UV-Vis spectral features) and MS scanning according to the procedure described by (Chandra, et al 2001) with some modifications. Samples were analysed using a Zorbax SB- C18 $(5 \mu \mathrm{m}, 4.6 \mathrm{~mm} \times 250 \mathrm{~mm})$ column at $30^{\circ} \mathrm{C}$. The following solvents in water with a flow rate of $1 \mathrm{ml}$ min-1 were used: A $(0.5 \%$ aqueous phosphoric acid $(\mathrm{v} / \mathrm{v})$ ) and $\mathrm{B}$ (water/acetonitrile/glacial acetic acid/phosphoric acid, 50:48.5:1.0: $0.5(\mathrm{v} / \mathrm{v} / \mathrm{v} / \mathrm{v}))$. The solvent gradient was $\% \mathrm{~B}$, initial, $20 \%$; $26 \mathrm{~min}$. $60 \%$; 30 min. 20\%; 35 min. 20\%.

\section{Hepatoprotective effects of MO extracts}

\section{Experimental animals}

Male albino rats of weighing 130-150 g were obtained from the animal house of National Organization for Drug Control and Research(NOD CAR). Animals were housed in an ambient temperature of $25^{\circ} \mathrm{C}+3.2^{\circ} \mathrm{C}$ on light/dark cycle of $12 / 12$ hours. All rats were kept in clean polypropylene cages and administered food and water.

Induction of hepatic stress by acetaminophen treatment

The acetaminophen (APAP) were dissolved in dimethyl sulfoxide (DSMO) at a concentration $4 \mathrm{~g}$ APAP/kg bw. 11 groups with 6 rats each received $1 \mathrm{~mL}$ oral administration of single dose of (APAP) dissolved in DMSO one day after treatment with $\mathrm{MO}$ extracts. Four groups received ethanolic extract of $\mathrm{MO}$ at $300 \mathrm{mg}$ or $600 \mathrm{mg}$ pods or leaves / 1 $\mathrm{ml}$ DMSO starting one day and continuous for 21 days before treating with APAP.

Blood samples from the retro-orbital were taken weekly through fine capillary glass tubes according to Schermer's (1967).

\section{Liver functions tests}

The following parameters were measured in serum, alanine aminotransferase (ALT), aspartate aminotransferase (AST), according to Reitman and Frankel (1957), $\gamma$-glutamyl transferase (GGT) according to Shaw, M. et al (1983), alkaline phosphatase (ALP) according to Belfield and Goldberg (1971) and total bilirubin according to Walter and Gerade (1970).

\section{Determination of oxidative-stress markers}

The biological system contains some enzymes such as catalase (CAT) and superoxide dismutase (SOD) which contribute in the defense process against reactive species. The level of these enzymes change under oxidative stress. Catalase activity in serum was determined according to the method described by Sinha A.K.(1972). The activity of SOD enzyme in serum was determined according to the procedure of Kiran, K.K. et al (2017)

Determination of malondialdehyde (MDA).

MDA in serum samples was determined according to the procedure of Kiran, K.K. et al (2017).

\section{Determination of urea}

Urea in serum was determined according to the procedure of Fawcett and Soctt, et al (1960).

\section{Determination of creatinine}

creatinine in serum was determined according to the procedure of Bartles, et al (1972).

Histopathological examination.

AT the end experiment (after 21 days), the rats were killed, and the liver was removed and stored in $10 \%$ formalin for histological evaluation.

\section{Statistical analysis}

The recorded data were treated statistically using the one way analysis of variance (ANOVA). The means were compared by Duncan's Multiple Range Test at $p<0.05$. Statistical analysis were performed using (SAS, 2006. Data Analysis of Various, Cary, NC). 


\section{RESULTS AND DISCUSSIONS}

\section{1-HPLC-MS analysis}

The ethanolic extract of MO was analyzed by HPLC-MS. five main fragment ion peaks $(354,431$, 463, 505 and 447) were observed which represent chlorogenic acid, Apigenin-8-C-glucoside, Quercetin-3-O- $\beta$-D-glucoside,Quercetin-3-O-acetyl glucoside and kaempferol-3-O-glucoside respectively. The antioxidant activity of $\mathrm{MO}$ ethanolic extract is due to the presence various bioactive compounds such as Quercetin glucoside, kaempferol glucoside, chlorogenic acid and rutin (Atawodi, et al 2010).

\section{2- DPPH scavenging activity of the different extracts of MO}

Table (1) illustrates the DPPH free radical scavenging activity of the ethanolic, aqueous and hexane extracts of different parts (leaves, Flowers, roots, pods and seeds) of the Moringa oleifera lam (MO) extracts at constant concentration of (12 $\mathrm{mg} / \mathrm{ml}$ extract). The highest antioxidant activity in term of \% inhibition was detected in ethanolic extracts followed by aqueous and finally hexane extract. Among the ethanolic extracts, the flowers have higher scavenging activity $(94.910 \%)$ than standard substance vitamin C $(94.000 \%)$ followed by leaves (93.100\%) and pods (90.786\%). Generally, it could be concluded that (1) ethanolic extract possessed significant highest antioxidant activity comparing to aqueous and hexane extracts. (2) the flowers, leaves and pods extract has also significant highest antioxidant activities compared to other parts of the plant. It has been reported that the chemical constituents are varying among the different parts of the same plant (Abdul K. et al 2009), and using different solvents due to variation of the solubilities of different bioactive compound (Koruthu, et al 2011).

3- Effect of MO leaves and pods ethanolic extracts in the liver function in APAP induced toxicity

Liver cells are highly susceptible to oxidative stress because it is a major organ attacked by reactive oxygen species (ROS). Parenchymal cells are primary cells subjected to oxidative stress induced injury in the liver. The metachondrion, microsomes and peroxisomes in parenchymal cells can produce ROS. Moreover, Kupffer cells, hepatic stellate cells and endothelial cells are potentially more exposed or sensitive to oxidative stress- related molecules (Sanchez-Valle, et al 2012). A disease process-which usually including oxidative stress- may cause changes in cell membrane permeability or increase cell death, resulting in release of intracellular enzymes. Increasing degree of tissue damage, increased the amount of released cellular components. Analyzing blood for cellular components represent a convenient way for clinicians to assess damage occurring elsewhere in the body.

3.1. Effects of (MO) leaves and pods ethanolic extracts on liver function enzymes in serum, ALT, AST, GGT and ALP.

The leaves and pods ethanolic extracts were evaluated for their potential antioxidant activity to study their hepatoprotective effect on APAPinduced hepatoxicity in rats. Levels of alanine aminotransferase (ALT), aspartate aminotransferase (AST), gamma ( $\mathrm{Y}$ ) glutamyl transferase (GGT), alkaline phosphatase (ALP), total protein and total bilirubin in the serum are used as a biochemical markers for evaluation of hepatic injury. The liver enzymes ALT, AST, GGT, ALP are concerned with intra cellular metabolism; they are released from the liver when cells become necrotic as in viral or toxic hepatic or cirrhosis, secreted into the serum at elevated levels in the presence of liver cell damage (Price and Steven, 2000). The results in Table (2) showed that, ALT, AST, GGT and ALP activity were increased significantly after oral administration with (APAP $4 \mathrm{~g} / \mathrm{kg} \mathrm{b.w}$ ) as compared with normal control rats after three weeks. All liver function markers enzymes activity were decreased in hepatotoxic induced rats treated with $M O$ leaves or pods extracts at levels of 300 and $600 \mathrm{mg} / \mathrm{kg}$. b.w. It concluded that Moringa oleifera lam extract has concentration dependent reducing effect on serum ALT, AST, GGT and ALP enzymes. Obtained results are in agreement with those of (Govindarajan Karthivashan, et al 2016); (Nevine, et al 2015) and (Mariam, et al 2014-2015). 


\section{Hepatoprotective effects of Moringa oleifera extracts on acetaminophen-induced 1577}

oxidative damage in rats

Table 1. The\% of DPPH radical scavenging inhibition activity of extracts of MO (at constant conc. of $12 \mathrm{mg}$ extract/ $\mathrm{ml}$ )

\begin{tabular}{|l|l|c|c|l|}
\hline \multicolumn{2}{|c|}{ The percentage of DPPH scavenging activity (\% inhibition) Mean values \pm S.E. } \\
\hline & Ethanolic extracts & Aqueous extracts & Hexane extracts & Vit C \\
& & & & \\
\hline Flowers & $94.916 \pm 2.031^{\mathrm{a}}$ & $72.666 \pm 1.763^{\mathrm{d}}$ & $17.333 \pm 0.881^{\mathrm{h}}$ & \\
Leaves & $93.101 \pm 0.935^{\mathrm{ab}}$ & $75.500 \pm 0.500^{\mathrm{d}}$ & $43.000 \pm 2.309^{\dagger}$ & \\
Pods & $90.786 \pm 1.015^{\mathrm{abc}}$ & $86.333 \pm 1.201^{\mathrm{bc}}$ & $40.333 \pm 1.452^{\dagger}$ & $\mathbf{9 4 . 0 0 0 \pm 1 . 1 7 1 ^ { \mathrm { a } }}$ \\
Roots & $84.803 \pm 2.952^{\mathrm{c}}$ & $58.333 \pm 1.201^{\mathrm{e}}$ & $25.333 \pm 2.603^{\mathrm{g}}$ & \\
Seeds & $62.150 \pm 5.500^{\mathrm{e}}$ & $63.333 \pm 2.603^{\mathrm{e}}$ & $12.666 \pm 1.452^{\mathrm{h}}$ & \\
\hline
\end{tabular}

Means with the same letters are not significant at $5 \%$

Table 2. Effect of ethanolic extract of MO leaves and pods on serum (ALT), (AST), GGT and ALP activity

\begin{tabular}{|c|c|c|c|c|c|c|c|c|}
\hline \multirow{2}{*}{ Treatment } & \multicolumn{2}{|c|}{$\begin{array}{l}\text { ALT } \\
\mathrm{U} / \mathrm{ml}\end{array}$} & \multicolumn{2}{|c|}{$\begin{array}{l}\text { AST } \\
\mathrm{U} / \mathrm{ml}\end{array}$} & \multicolumn{2}{|c|}{$\begin{array}{l}\text { GGT } \\
\mathrm{U} / \mathrm{ml}\end{array}$} & \multicolumn{2}{|c|}{$\begin{array}{l}\text { ALP } \\
\text { IU/L }\end{array}$} \\
\hline & Zero time & Week 3 & Zero time & Week 3 & Zero time & Week 3 & Zero time & Week 3 \\
\hline $\begin{array}{l}\text { Normal Control } \\
\% \text { Change }\end{array}$ & $\begin{array}{c}51.434 \pm \\
0.957^{a} \\
125.4 \%\end{array}$ & $\begin{array}{c}40.269 \pm \\
0.662^{a} \\
40.3 \%\end{array}$ & $\begin{array}{c}54.767 \pm \\
1.258^{\mathrm{a}} \\
119.5 \%\end{array}$ & $\begin{array}{c}45.508 \pm \\
0.993^{\mathrm{b}} \\
40.7 \%\end{array}$ & $\begin{array}{c}8.299 \pm \\
1.477^{\mathrm{a}} \\
195.5 \%\end{array}$ & $\begin{array}{l}8.874 \pm \\
0.433^{b} \\
19.2 \%\end{array}$ & $\begin{array}{c}173.182 \pm \\
5.943^{\mathrm{c}} \\
86.2 \%\end{array}$ & $\begin{array}{c}161.165 \pm \\
8.201^{b} \\
31.3 \%\end{array}$ \\
\hline $\begin{array}{l}\text { Negative Control } \\
\quad(\mathrm{DMSO})\end{array}$ & $\begin{array}{c}49.390 \pm \\
1.048^{\mathrm{a}}\end{array}$ & $\begin{array}{c}38.931 \pm \\
1.045^{\mathrm{b}}\end{array}$ & $\begin{array}{c}53.917 \pm \\
0.404^{\mathrm{a}}\end{array}$ & $\begin{array}{c}44.017 \pm \\
0.790^{\mathrm{b}}\end{array}$ & $\begin{array}{l}6.369 \pm \\
1.223^{\mathrm{abc}}\end{array}$ & $\begin{array}{l}7.141 \pm \\
0.676^{b}\end{array}$ & $\begin{array}{c}165.528 \pm \\
3.897^{\circ}\end{array}$ & $\begin{array}{c}138.228 \pm \\
3.701^{\mathrm{b}}\end{array}$ \\
\hline$\%$ Change & $120.4 \%$ & $38.9 \%$ & $117.6 \%$ & $39.4 \%$ & $150 \%$ & $15.4 \%$ & $82.4 \%$ & $26.8 \%$ \\
\hline $\begin{array}{c}\text { Positive Control } \\
\text { (APAP) } 4 \mathrm{~g} / \mathrm{kg}\end{array}$ & $\begin{array}{c}41.021 \pm \\
0.520^{\circ}\end{array}$ & $\begin{array}{c}100.027 \pm \\
1.625^{\mathrm{a}}\end{array}$ & $\begin{array}{c}45.845 \pm \\
0.399^{b}\end{array}$ & $\begin{array}{c}111.833 \pm \\
1.548^{\mathrm{a}}\end{array}$ & $\begin{array}{l}4.246 \pm \\
0.553^{c}\end{array}$ & $\begin{array}{c}46.304 \pm \\
2.856^{\mathrm{a}}\end{array}$ & $\begin{array}{c}200.870 \pm \\
0.300^{\mathrm{b}}\end{array}$ & $\begin{array}{c}514.915 \pm \\
63.592^{\mathrm{a}}\end{array}$ \\
\hline $\begin{array}{c}\text { b.w } \\
\text { \% Change }\end{array}$ & $100 \%$ & $100 \%$ & $100 \%$ & $100 \%$ & $100 \%$ & $100 \%$ & $100 \%$ & $100 \%$ \\
\hline MOLE $300 \mathrm{mg} / \mathrm{kg}$ & $43.658 \pm$ & $35.603 \pm$ & $47.717 \pm$ & $40.878 \pm$ & $6.948 \pm$ & $3.667 \pm$ & $173.975 \pm$ & $122.322 \pm$ \\
\hline b.w & $0.203^{b}$ & $0.770^{c}$ & $0.719^{b}$ & $0.252^{\mathrm{c}}$ & $0.598^{\mathrm{ab}}$ & $0.22^{\mathrm{C}}$ & $8.005^{c}$ & $7.423^{b c}$ \\
\hline$\%$ Change & $106.4 \%$ & $35.6 \%$ & $104.1 \%$ & $36.6 \%$ & $163.6 \%$ & $7.9 \%$ & $86.6 \%$ & $23.85 \%$ \\
\hline MOLE $600 \mathrm{mg} / \mathrm{kg}$ & $50.050 \pm$ & $33.880 \pm$ & $54.175 \pm$ & $40.300 \pm$ & $5.211 \pm$ & $3.088 \pm$ & $218.578 \pm$ & $119.445 \pm$ \\
\hline b.w & $0.611^{\mathrm{a}}$ & $0.743^{\mathrm{cd}}$ & $0.441^{\mathrm{a}}$ & $0.714^{\mathrm{c}}$ & $0.704^{\mathrm{bc}}$ & $0.548^{c}$ & $6.575^{\mathrm{b}}$ & $6.858^{\mathrm{bc}}$ \\
\hline$\%$ Change & $122.0 \%$ & $33.9 \%$ & $118.2 \%$ & $36.0 \%$ & $122.7 \%$ & $6.7 \%$ & $108.8 \%$ & $23.2 \%$ \\
\hline MOPE & $51.187 \pm$ & $32.165 \pm$ & $55.797 \pm$ & $36.838 \pm$ & $6.755 \pm$ & $3.005 \pm$ & $261.900 \pm$ & $112.952 \pm$ \\
\hline $300 \mathrm{mg} / \mathrm{kg} \mathrm{b.w}$ & $0.776^{a}$ & $1.089^{d}$ & $0.668^{\mathrm{a}}$ & $0.946^{d}$ & $0.612^{\mathrm{abc}}$ & $0.275^{c}$ & $19.124^{a}$ & $4.499^{b c}$ \\
\hline$\%$ Change & $124.8 \%$ & $32.2 \%$ & $121.7 \%$ & $32.9 \%$ & $159.1 \%$ & $6.5 \%$ & $130.4 \%$ & $21.9 \%$ \\
\hline MOPE & $45.247 \pm$ & $28.837 \pm$ & $54.458 \pm$ & $34.673 \pm$ & $7.861 \pm$ & $2.509 \pm$ & $200.605 \pm$ & $64.342 \pm$ \\
\hline $600 \mathrm{mg} / \mathrm{kg}$ b.w & $1.335^{\mathrm{b}}$ & $0.118^{\mathrm{e}}$ & $1.590^{\mathrm{a}}$ & $0.755^{\mathrm{d}}$ & $0.516^{\mathrm{a}}$ & $0.435^{c}$ & $0.579^{b}$ & $4.103^{c}$ \\
\hline$\%$ Change & $110.3 \%$ & $28.8 \%$ & $118.8 \%$ & $31.0 \%$ & $185.1 \%$ & $5.4 \%$ & $99.9 \%$ & $12.5 \%$ \\
\hline
\end{tabular}

$a, b, c, d$, e Values of 6 rats means \pm S.E., Means with the same letter are not significant different, $\%$ change from positive control ( $100 \%$ toxicity), at $\mathrm{P}<0.05$ 
3.2. Effects of (MO) leaves and pods ethanolic extracts on serum total bilirubin (T.BIL) and total protein

The results in Table (3) showed that, (T.BIL) was increased to $(6.001 \mathrm{mg} / \mathrm{dl})$ after oral administered with (APAP $4 \mathrm{~g} / \mathrm{kg}$ b.w) as compared with normal control rats $(3.738 \mathrm{mg} / \mathrm{dl})$ after 3 weeks, and in hepatotoxic induced rats the T. Protein was significantly decreased compared with either negative or normal controls. T.BIL was noticed significant decrease after 3 weeks in groups that treated with MO leaves and pods extracts at doses of 300 and $600 \mathrm{mg} / \mathrm{kg}$.b.w. On the other hand, T. Protein in serum was increased in hepatotoxic induced rats treated with $\mathrm{MO}$ extract leaves and pods at the two doses used in experiment. The obtained results rerefers to the concentration dependent effect of extracts used either from leaves or pods. The ethanolic extract of pods was showed no significant difference compared with ethanolic extract of leaves on serum T.BIL and total protein. Obtained results agreed with Marzan Sarkar, et al (2017) \& Nevine, et al (2015).

3.3. Effect of Moringa Oleifera lam(MO) leaves and pods ethanolic extracts on oxidative markers in serum , malondialdehyde (MDA), superoxide dismutase (SOD) and catalase (CAT).

Malondialdehyde (MDA) the toxic end product of lipid peroxidation in serum (K Gayathri., et al 2011) was studied in table (4). MDA was significantly elevated after treatment with (APAP $4 \mathrm{~g} / \mathrm{kg}$ b.w) by $(0.341 \mathrm{nmol} / \mathrm{ml})$ as compared with normal control rats $(0.058 \mathrm{nmol} / \mathrm{ml})$ after 3 weeks. Treatment with Moringa Oleifera lam extracts used in this experiment at the two doses 300 and $600 \mathrm{mg} / \mathrm{kg} . \mathrm{b} . \mathrm{w}$ resulted in significant decrease in MDA in hepatotoxic induced rats. SOD is the first enzyme involved in the antioxidant defense by lowering the steady state $\mathrm{O}_{2}^{-*}$, it $\mathrm{s}$ a member of a mutually supportive team of defense against reactive oxygen species (ROS) (Nevin and Vijayammal, 2005). Data presented in Table (4) showed that, (SOD) was decreased significantly after treatment with (APAP $4 \mathrm{~g} / \mathrm{kg} \mathrm{b.} \mathrm{w)} \mathrm{compared}$ with normal control rats after 3 weeks, SOD was recovered in hepatotoxic induced rats treated with Moringa Oleifera lam extracts and the elevation in SOD activity was corelated with either leaves or pods extract level. Similarly, Moringa Oleifera lam extracts of leaves and pods at levels of 300 and
$600 \mathrm{mg} / \mathrm{kg} . \mathrm{b} . \mathrm{w}$. significantly decreased the catalase activity in serum by $(20.552,24.356$, and 67.807, $71.426 \mathrm{mmol} / \mathrm{min} / \mathrm{ML}$ ) respectively. Our findings are in agreement with those of (Sharida Fakurazi., et al 2012) and (Mariam., et al 20142015).

\section{Histopathological result of the pathological analysis of the biological experiment}

Figures 1, 2, 3 and 4 showed results of the histopathological analysis of the liver for rats treated with 300 or $600 \mathrm{mg} / \mathrm{kg} \mathrm{b.w}$. of ethanolic extract of either leaves or pods of Moringa Oleifera lam. Fig. 1 had an average change and Fig. 2 had a change below average and Fig. 3 Simple, Fig. 4 have slight pathological changes, The effects are due to the active $\mathrm{MO}$ extract in liver cell repair by activating antioxidant enzymes.

The pods extract was found to be more effective than the leaves extract and the effect was found to be concentration dependent.

5. Effect of Moringa Oleifera lam (MO) leaves and pods ethanolic extracts on the kidney function (serum urea and creatinine) in APAP induced toxicity

Data presented in Table (5) showed that, urea and creatinine $(\mathrm{CR})$ were significantly elevated after oral administration of (APAP $4 \mathrm{~g} / \mathrm{kg} \mathrm{b.w)} \mathrm{as}$ compared with normal control rats after 3 weeks of treatment, urea was decreased in hepatotoxicity rats treated with Moringa Oleifera lam leaves and pods extracts at the two doses 300 and 600 $\mathrm{mg} / \mathrm{kg}$. b.w. Similarly, creatinine (CR) was increased after treatment with (APAP $4 \mathrm{~g} / \mathrm{kg}$ b.w) by $(0.702 \mathrm{mg} / \mathrm{dl})$ as compared with normal control rats $(3.738 \mathrm{mg} / \mathrm{dl})$ after 3 weeks. After 3 weeks treatment with Moringa Oleifera lam extracts of leaves and pods at the two doses 300 and $600 \mathrm{mg} / \mathrm{kg}$.b.w. (CR) was decreased significantly in hepatotoxic induced rats. Reduction in CR in serum was noticed to be corelated with the extract concentration used. our findings are in agreement with those of (Govindarajan Karthivashan., et al 2016). Relationship of the liver to the kidney when paracetamol poisoning (acetaminophen). The occurrence of renal failure before liver damage, is indicating that the dose of paracetamol in the kidneys is lower than the liver dose. Liver damage results not from paracetamol itself, but from one of its metabolites, $N$-acetyl-p-benzoquinone imine (NAPQI). NAPQI 


\section{Hepatoprotective effects of Moringa oleifera extracts on acetaminophen-induced 1579}

oxidative damage in rats

Table 3. Effect of ethanolic extract of MO leaves and pods on serum T. Bil, and T. protein

\begin{tabular}{|l|c|c|c|c|}
\hline \multirow{2}{*}{ Treatment } & \multicolumn{2}{c|}{$\begin{array}{c}\text { T.Bil } \\
\text { mg/dl }\end{array}$} & \multicolumn{2}{c|}{$\begin{array}{c}\text { T. protein } \\
\text { g/dl }\end{array}$} \\
\cline { 2 - 5 } & Zero time & Week 3 & Zero time & Week 3 \\
\hline Normal Control & $4.956 \pm 0.328^{\mathrm{ab}}$ & $3.738 \pm 0.848^{\mathrm{b}}$ & $5.898 \pm 0.132^{\mathrm{a}}$ & $6.137 \pm 0.095^{\mathrm{bc}}$ \\
Negative Control & $5.070 \pm 0.172^{\mathrm{a}}$ & $2.967 \pm 0.390^{\mathrm{b}}$ & $5.833 \pm 0.113^{\mathrm{a}}$ & $5.542 \pm 0.368^{\mathrm{c}}$ \\
& & & & \\
(DMSO) & $5.005 \pm 0.314^{\mathrm{ab}}$ & $6.001 \pm 1.068^{\mathrm{a}}$ & $6.112 \pm 0.250^{\mathrm{a}}$ & $2.769 \pm 0.094^{\mathrm{d}}$ \\
& & & & \\
Positive Control & & & & \\
(APAP) 4g/kg b.w & $4.172 \pm 0.254^{\mathrm{abc}}$ & $0.207 \pm 0.074^{\mathrm{c}}$ & $5.783 \pm 0.113^{\mathrm{ab}}$ & $6.475 \pm 0.248^{\mathrm{b}}$ \\
MOLE 300mg/kg b.w & $4.293 \pm 0.450^{\mathrm{bc}}$ & $0.129 \pm 0.053^{\mathrm{c}}$ & $5.967 \pm 0.175^{\mathrm{a}}$ & $7.640 \pm 0.366^{\mathrm{a}}$ \\
MOLE 600mg/kg b.w & $3.570 \pm 0.269^{\mathrm{c}}$ & $0.099 \pm 0.025^{\mathrm{c}}$ & $5.243 \pm 0.177^{\mathrm{b}}$ & $8.223 \pm 0.107^{\mathrm{a}}$ \\
MOPE 300mg/kg b.w & $3.747 \pm 0.423 \mathrm{c}$ & $0.054 \pm 0.015^{\mathrm{c}}$ & $5.795 \pm 0.137^{\mathrm{ab}}$ & $8.230 \pm 0.187^{\mathrm{a}}$ \\
\hline MOPE 600mg/kg b.w & & & & \\
\hline
\end{tabular}

a,b,c,d ,e Values of 6 rats means \pm S.E., Means with the letter are not significant different, , Number in the same column followed by the same letters are not significant at $\mathrm{P}<0.05$.

Table 4. Effect of ethanolic extract of Moringa Oleifera lam (MO) leaves and pods on serum malondialdehyde (MDA), serum superoxide dismutase (SOD) and serum catalase (CAT) activity

\begin{tabular}{|c|c|c|c|c|c|c|}
\hline \multirow{2}{*}{ Treatment } & \multicolumn{2}{|c|}{$\begin{array}{c}\text { MDA } \\
(\mathrm{nmol} / \mathrm{ml})\end{array}$} & \multicolumn{2}{|c|}{$\begin{array}{l}\text { SOD } \\
\mathrm{U} / \mathrm{ml}\end{array}$} & \multicolumn{2}{|c|}{$\begin{array}{l}\text { Catalase Activi- } \\
\text { ty(mmol/min/mL) }\end{array}$} \\
\hline & Zero time & Week 3 & Zero time & Week 3 & Zero time & Week 3 \\
\hline $\begin{array}{l}\text { Normal } \\
\text { Control }\end{array}$ & $0.067 \pm 0.013^{a}$ & $0.058 \pm 0.011^{b}$ & $153.960 \pm 13.8^{a}$ & $179.703 \pm 19.391^{c}$ & $3.835 \pm 0.365^{a b}$ & $4.013 \pm 0.265^{c}$ \\
\hline $\begin{array}{c}\text { Negative } \\
\text { Control } \\
\text { (DMSO) } \\
\text { Positive }\end{array}$ & $0.071 \pm 0.027^{\mathrm{a}}$ & $0.049 \pm 0.002^{b}$ & $149.340 \pm 15.947^{\mathrm{a}}$ & $189.604 \pm 17.670^{\circ}$ & $3.533 \pm 0.076^{\mathrm{ab}}$ & $4.113 \pm 0.204^{c}$ \\
\hline $\begin{array}{c}\text { Control } \\
\text { (APAP) } 4 \mathrm{~g} / \mathrm{kg} \\
\text { b.w }\end{array}$ & $0.075 \pm 0.014^{\mathrm{a}}$ & $0.341 \pm 0.085^{a}$ & $154.291 \pm 19.206^{a}$ & $63.201 \pm 8.410^{d}$ & $3.919 \pm 0.171^{a}$ & $2.302 \pm 0.317^{c}$ \\
\hline $\begin{array}{c}\text { MOLE } \\
300 \mathrm{mg} / \mathrm{kg} \\
\text { b.w }\end{array}$ & $0.098 \pm 0.029^{\mathrm{a}}$ & $0.035 \pm 0.004^{b}$ & $159.571 \pm 19.634^{\mathrm{a}}$ & $477.393 \pm 16.854^{b}$ & $3.811 \pm 0.238^{\mathrm{ab}}$ & $20.552 \pm 1.051^{b}$ \\
\hline $\begin{array}{c}\text { MOLE } \\
600 \mathrm{mg} / \mathrm{kg} \\
\text { b.w }\end{array}$ & $0.091 \pm 0.013^{\mathrm{a}}$ & $0.034 \pm 0.005^{b}$ & $99.505 \pm 12.121^{b}$ & $489.934 \pm 42.167^{b}$ & $3.215 \pm 0.191^{b}$ & $24.356 \pm 0.778^{b}$ \\
\hline $\begin{array}{c}\text { MOPE } \\
300 \mathrm{mg} / \mathrm{kg} \\
\text { b.w }\end{array}$ & $0.131 \pm 0.020^{\mathrm{a}}$ & $0.027 \pm 0.008^{b}$ & $151.650 \pm 19.864^{a}$ & $503.135 \pm 12.073^{\mathrm{b}}$ & $3.216 \pm 0.257^{b}$ & $67.807 \pm 7.456^{a}$ \\
\hline $\begin{array}{c}\text { MOPE } \\
600 \mathrm{mg} / \mathrm{kg} \\
\text { b.w }\end{array}$ & $0.127 \pm 0.035^{\mathrm{a}}$ & $0.022 \pm 0.003^{b}$ & $93.069 \pm 4.532^{\mathrm{b}}$ & $596.370 \pm 16.815^{a}$ & $3.362 \pm 0.284^{\mathrm{ab}}$ & $71.426 \pm 11.041^{\mathrm{a}}$ \\
\hline
\end{tabular}

a,b,c,d Values of 6 rats means \pm S.E., Means with the letter are not significant different, , Number in the same column followed by the same letters are not significant at $P<0.05$. 


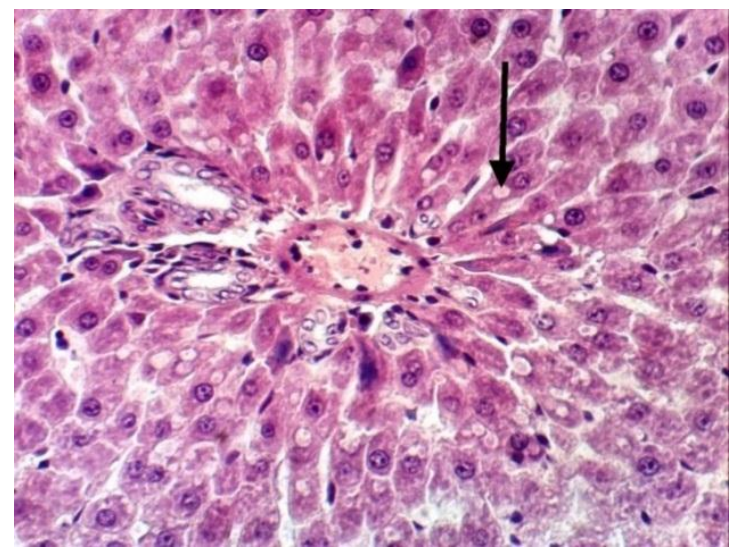

Fig. 1. Liver of rat from group leaves extract 300 showing vacuolar degeneration of hepatocytes $(\mathrm{H}$ \& EX 400).

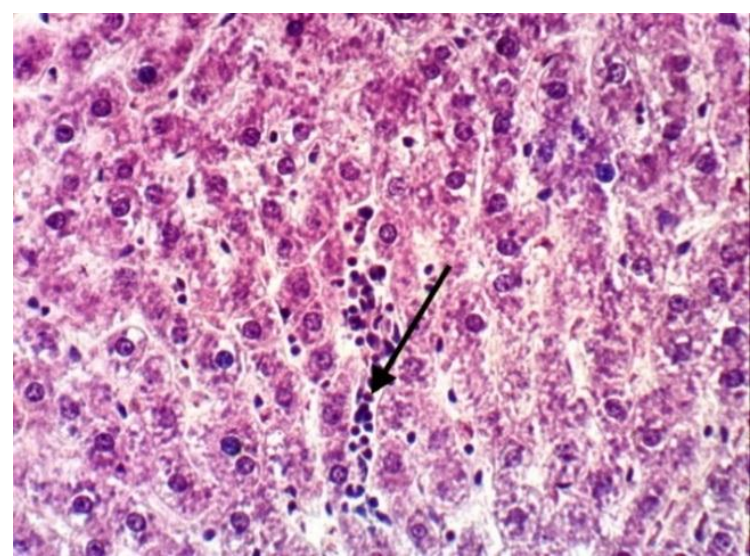

Fig. 3. Liver of rat from group pods extract 300 showing sinusoidal leucocytosis (H \& E X 400)

decreases the liver's glutathione and directly damages cells in the liver according to Webb, Andrew, et al (2016). The end- product of creatine metabolism in muscles is creatinine. In renal failure, creatinine is retained with other non-protein nitrogen of the blood. hence, serum creatinine level increases in cases of kidney diseases. Consequently, the determination of creatinine level in serum can be considered as a good index for renal impairment rather than serum urea (Baron, 1987). Therefore, kidney function was analyzed. Paracetamol overdose cause a marked proteinuria and glucosuria with a significant increase creatinine and urea plasma levels (Trumper et al 1998). High dose Paracetamol administration caused, marked depletion of GSH levels and antioxidant enzyme

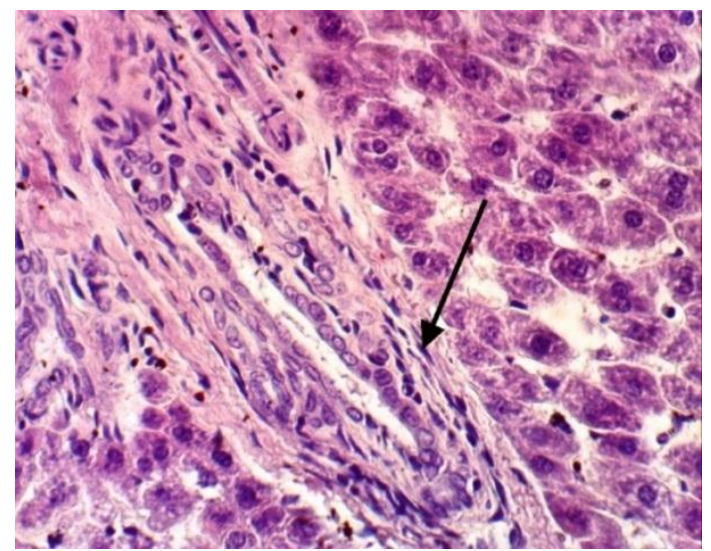

Fig. 2. Liver of rat from group leaves extract 600 showing fibroplasia in the portal triad $(\mathrm{H}$ \& EX 400).

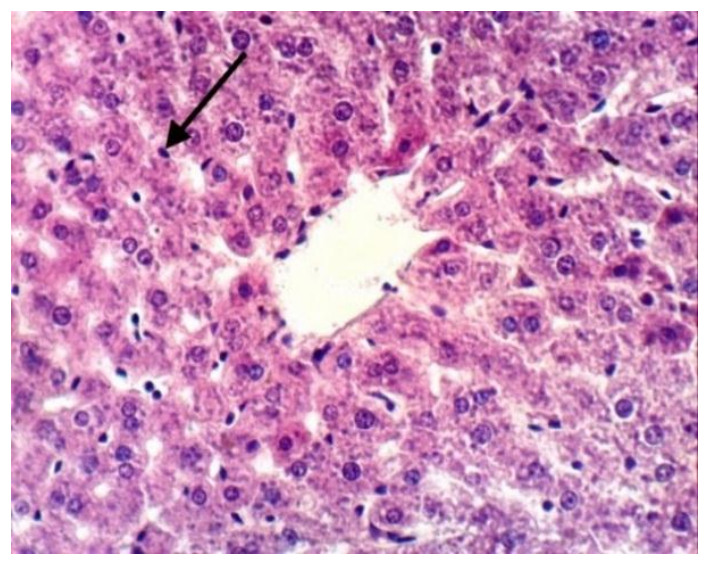

Fig. 4. Liver of rat from group pods extract 600 showing slight activation of Kupffer cells ( $H$ \& $E$ X 400).

activity (Cekmen et al 2009), and is often associated with a wide range of metabolic disorders including serum electrolytes, urea and creatinine. The renal functions with the increased serum urea and creatinine levels are considered one of the most documented parameters for investigating drug induced nephrotoxicity in animals and man (Adelman et al 1981). High dose of Paracetamol caused renal insufficiency is consistent with acute tubular necrosis, an increase in the plasma creatinine level and a decrease in the glomerular filtration rate (GFR). The development of ARF in rats within $24 \mathrm{hrs}$ by oral administration of a single dose of acetaminophen $(750 \mathrm{mg} / \mathrm{kg}$ ) was reported (Pelani et al 2009). 
Table 5. Effect of ethanolic extract of Moringa Oleifera lam (MO) leaves and pods on kidney function parameters in serum (urea and creatinine)

\begin{tabular}{|c|c|c|c|c|}
\hline \multirow{2}{*}{ Treatment } & \multicolumn{2}{|c|}{ Urea(mg/dl) } & \multicolumn{2}{c|}{ creatinine g/dl } \\
\cline { 2 - 5 } & Zero time & Week 3 & Zero time & Week 3 \\
\hline Normal Control & $44.770 \pm 4.214^{\mathrm{a}}$ & $44.563 \pm 1.706^{\mathrm{c}}$ & $1.040 \pm 0.076^{\mathrm{ab}}$ & $0.702 \pm 0.143^{\mathrm{b}}$ \\
$\%$ Change & $98.1 \%$ & $22.7 \%$ & $97.5 \%$ & $14.5 \%$ \\
Negative Control & $49.455 \pm 3.364^{\mathrm{a}}$ & $56.107 \pm 3.802^{\mathrm{bc}}$ & $1.128 \pm 0.245^{\mathrm{ab}}$ & $0.728 \pm 0.102^{\mathrm{b}}$ \\
(DMSO) & $108.4 \%$ & $28.6 \%$ & $105.7 \%$ & $15.0 \%$ \\
$\%$ Change & & & & \\
Positive Control & $45.643 \pm 2.677^{\mathrm{a}}$ & $196.123 \pm 13.094^{\mathrm{a}}$ & $1.067 \pm 0.181^{\mathrm{ab}}$ & $4.842 \pm 0.816^{\mathrm{a}}$ \\
(APAP)4g/kg b.w & $100 \%$ & $100 \%$ & $100 \%$ & $100 \%$ \\
$\%$ Change & & & & \\
MOLE 300mg/kg b.w & $54.678 \pm 5.860^{\mathrm{a}}$ & $81.417 \pm 10.729^{\mathrm{b}}$ & $0.963 \pm 0.047^{\mathrm{b}}$ & $0.408 \pm 0.078^{\mathrm{b}}$ \\
$\%$ Change & 119.8 & $41.5 \%$ & $90.3 \%$ & $8.4 \%$ \\
MOLE 600mg/kg b.w & $44.830 \pm 2.006^{\mathrm{a}}$ & $65.107 \pm 15.852^{\mathrm{bc}}$ & $1.337 \pm 0.139^{\mathrm{ab}}$ & $0.380 \pm 0.090^{\mathrm{b}}$ \\
$\%$ Change & $98.2 \%$ & $33.2 \%$ & $125.3 \%$ & $7.8 \%$ \\
MOPE 300mg/kg b.w & $54.367 \pm 1.508^{\mathrm{a}}$ & $59.407 \pm 2.523^{\mathrm{bc}}$ & $1.603 \pm 0.451^{\mathrm{a}}$ & $0.345 \pm 0.028^{\mathrm{b}}$ \\
$\% C h a n g e$ & $119.1 \%$ & $30.3 \%$ & $150.2 \%$ & $7.1 \%$ \\
MOPE 600mg/kg b.w & $47.550 \pm 7.454^{\mathrm{a}}$ & $40.730 \pm 3.397^{\mathrm{c}}$ & $1.153 \pm 0.096^{\mathrm{ab}}$ & $0.242 \pm 0.032^{\mathrm{b}}$ \\
$\%$ Change & $104.2 \%$ & $20.8 \%$ & 108.1 & $5.0 \%$ \\
\hline
\end{tabular}

a,b,c,d ,e Values of 6 rats means \pm S.E., Means with the letter are not significant different, \%change from positive control ( $100 \%$ toxicity), Number in the same column followed by the same letters are not significant at $P<0.05$.

\section{CONCLUSION}

Ethanolic extract of $\mathrm{MO}$ leaves and pods is an active in treating liver toxicity caused by drugs like Acetaminophen. The effect on liver and kidney was found to be a concentration dependent means that the active ingredients in both leaves and pods are similar and high level was correlated with the protective effect against hepatotoxicity.

\section{REFERENCES}

Adelman, R.D., Spangler, W.L., F. Beasom,. Ishizaki, G. and Conzelman, G.M. 1981. Frusemide enhancement of neltimicin nephrotoxicity in dogs. J. of Antimicrobials and Chemothemotherapy., 7, 431-435.

Anwar, F., Latif, S., Ashraf, M. and Gilani, A.H. 2007. Moringa Oleifera : A food plant with multiple medicinal uses, phytother. Res., 21, 1725.

Ashok, K.N. and Pari, L. 2003. Antioxidant action of Moringa Oleifera lam (drumstick) against antitubercular drugs induced lipid peroxidation in rats. J. Med. Food, 6, 255-259.

Atawodi, S.E., Atwodi, J.C., Idakw, G.A., Pfundstien, B., Haubner, R., Wurtele, G., Bartsch, H. and Owen, R.H. 2010. Evaluation of the polyphenol content and antioxidant properties of methanol extracts of the leaves, stem, and root barks of Moringa Oleifera lam., I. Med. Food, 13, 710-716.

Baron, D.N. 1987. A short textbook of chemical pathology, $4^{\text {th }}$ edition- English Language Book Society/Hodder and Stoughton Ltd, Mill Road, Dunton Green, Sevenoaks, Kent, Great Britain, pp. 188-228.

Bartles, H., Bohmer, M. and Heirli, C. 1972. Clin, Chem, Acta 37, 193 and Belfield A, and Goldberg $D$. Colorimetric determination of alkaline phosphatase activity. Enzyme, 12, 561-566.

Brand-Williams, W., Cuvelier, M.E. and Berset, C. 1995. Use of a free radical Method to Evaluate Antioxidant Activity, Lebensm.-Wiss. u.Technol., 28, 25-30.

Cekmen, M., Ilbey, Y.O., Ozbek, E., Simsek, A., Somay, A. and Ersoz, C. 2009. Curcumin prevents oxidative renal damage induced by acetaminophen in rats Food Chem. Toxicol., 47, 1480-1484.

Chandra, A., Rana, J. and Li, Y. 2001. Seperation, identification, quantification, and method validation of anthocyanins in botanical supplement raw materials by HPLC and HPLC-MS. J. Agric. Food Chem. 49, 3515-3521. 
Christina Frank, Mostafa K Mohamed, G Thomas Strickland, Daniel Lavanchy, Ray R. Arthur, Laurence S. Magder, Taha El Khoby, Yehia Abdel-Wahab, El Said Aly Ohn, Wagida Anwar, Ismail Sallam 2000. The role of parenteral antischistosomal therapy in the spread of hepatitis $C$ virus in Egypt. THE LANCET • $355 \mathrm{p}$.

Fawcett, J.K. and Soctt, J.E. 1960. J. Clin., Path. 13, 156 - 159.

Gayathri, K., Jayachandran, K.S., Hannah, Vasanthi, R. and Victor Rajamanickam, G. 2011. Cardioprotective effect of lemon grass as evidenced by biochemical and histopathological changes in experimentally induced cardiotoxicity, Human and Experimental Toxicology 30(8), 1073-1082.

Gornal, A.C. Bardawill, C.J..and David, M.M. 1949. J. Biol. Chem. 177, 751-755.

Govindarajan Karthivashan, Aminu Umar Kura, Palanisamy Arulselvan,Norhaszalina Md. Isa and Sharida Fakurazi, 2016. The modulatory effect of Moringa oleifera leaf extract on endogenous antioxidant systems and inflammatory markers in an acetaminophen-induced nephrotoxic mice model,10.7717/peerj. pp. 21-27.

Jaeschke H. and Bajt, M.L. 2006. Intracellular signaling mechanisms of acetaminopheninduced liver cell death. Toxicol. Sci., 89, 3141.

Kiran Kumar Kattappagari, Desai Vidya, Sivapradobh Vuddandi,Charani Ratnakar Gummalla and venketa Ramana ReddyBaddam. 2017. Oral submucous fibrosis: A quantitative assessment of serum malondialdehyde, superoxide dismutase and correlation with clinical staging, J. Oral Maxillofac Pathol., 21(1), 41-45.

Larsen, K. 1972. Clin. Chem. Acta 41, 209.

Mariam G. Eshak, M.M. Hassanane, Ibrahim M. Farag, Nermeen M. Shaffie and Aboelfetoh M. Abdalla 2014-2015. Evaluation of Protective and Therapeutic Role of Moringa Oleifera leaf extract on CCL4-induced genotoxicity, Hemotoxicity and Hepatotoxicity in Rats 7(2), 392-415.

Marzan Sarkar, Sujan Bhowmick, Jakir Hussain, Mahmudul Hasan, Shahdat Hossain 2017. Hot Water Extract of Moringa oleifera Leaves Protects Erythrocytes from Hemolysis and Major Organs from Oxidative Stress in vitro. J. basic appl. Res 3(3), 120-126.

method to evaluate antioxidant activity. Lebensm. Wiss. Technol. 28, 25-30.
Nevin, K.G. and Vijayammal, P.L. 2005. Effect of Avera lanata against hepatotoxicity of $\mathrm{CCl}_{4}$ in rats. Enviro. Toxicol. and Pharmacol., 792799.

Nevine R. Taha, Samar O. Rabah, Soad A. Shaker and Maysoon M. Mograby 2015. Effect of Moringa oleifera Leaves on Diclofenac Sodium Induced Hepatic Injury in Albino Rats: Ultrastructural and Immunohistochemical Studies, J. Cytol Histo pp. I6-2I.

Palma H.E., Wolkmer P., Gallio M., Correa M.M., Schmatz R., Thome G.R., Pereira L.B., Castro V.S., Pereira A.B., Bueno, A. 2014. Oxidative stress parameters in blood, liver, and kidney of diabetic rats treated with curcumin and/or insulin. Mol. Cell. Biochem., 386, 199210. doi: 10.1007/s11010-013-1858-5.

Pelani, S., Kumar, R.P. and Kumar, B.S. 2009. Effect of the ethanolic extract of Indiogofera barberi(L.) in acute acetaminopheninduced nephrotoxic rats. New Biotechnol., 25, 14-24.

Price, A. and Stevens, P. 2000. In: Experimental of clinical enzymology. Academic Press, N.Y. $404 \mathrm{p}$.

Reitman S. and Frankel, S. 1957. A colorimetric method for determination of serum glutamate oxaloacetate and glutamic pyruvate transaminase. Am. J. Clin. Pathol. 28, 56-58.

Sanchez-Valle, V., Chavez-Tapia, N.C., Uribe, M. and Mendez-Sanchez, N. 2012. Role of oxidative stress and molecular changes in liver fibrosis: A review. Curr. Med. Chem. 19, 48504860. doi: 10.2174/092986712803341520.

Schermer, S. 1967. The blood morphology of lab. .Animals, $3^{\text {rd }}$ Ed. 42 p. Davis, F.A., company Philadelphia, U.S.A.

Sha Li, Hor-Yue Tan, Ning Wang, Zhang-Jin Zhang, Lixing Lao,Chl-Woon Wong and Yibin Feng, 2015. The role of oxidative stress and antioxidants in liver DISEASES. Int. J. Mol. Sci.16, 2608-2614.

Sharida Fakurazi, Hairuszah and Nanthini Uma 2008. Moringa oleifera Lam prevents acetaminophen induced liver injury through restoration of glutathione level. Article in Food and Chemical Toxicology. September 2008 DOI: 10.1016/j.fct.2008.04.018 · Source: PubMed

Sharida, Fakurazi., Syazana, A.S. and Palanisamy, A. 2012. Mringa Oleifera hydrethanolic extracts effectively alleviate acetaminophen-induced hepatotoxicity in experimental rats through their antioxidant nature. Molecules, 17, 8334-8350. 


\section{Hepatoprotective effects of Moringa oleifera extracts on acetaminophen-induced 1583}

oxidative damage in rats

Shaw L.M., Stromme, J.H., London, J.L. and Theodorsen, L 1983. Methods for gammaglutamyltransferase[(gamma-glutamyl)-peptide: aminoacid gamma-glutamyltransferase, EC 2.3.2.2]. Int. J. of Clinical Chemistry. 135(3), 315-338.

Sinha, A.K. 1972. Colorimetric Assay of catalase. Analytical Biochemistry, 47(2), 389-94.

Streelatha, S. and Padma, P.R. 2011. Modulatory effects of Moriblnga Oleifera extracts against hydrogen peroxide-induced cytotoxicity and oxidative damage. Hum. Exp. Toxicol., 30, 13591368.
Trumper, L, Monasterolo, L. and Eli as, M. 1998. Probenecid protects against In Vivo Acetaminophen-Induced Nephrotoxicity in Male Wistar Rats. JPET 284, 606-610.

Walter, M. and Gerarde, H. 1970. Ultramicromethod for the determination of conjugated and total bilirubin in serum or plasma. Microchemistry J. 15, 231-36.

Webb, Andrew; Gattinoni, Luciano 2016. Oxford Textbook of Critical Care. Oxford University Press. 1518 p. ISBN 9780199600830. 